\begin{tabular}{c} 
Volume and Issues Obtainable at Center for Sustainability Research and Consultancy \\
Journal of Business and Social Review in Emerging Economies \\
ISSN: 2519-089X (E): 2519-0326 \\
Volume 5: No. 1, June 2019 \\
CSRᄃ \\
Journal homepage: www.publishing.globalcsrc.org/jbsee \\
\hline
\end{tabular}

\title{
Supply and Demand of the Entry-Level Job Competencies in the Hotel Industry
}

\author{
${ }^{1}$ Siti Fatimah Mohamad, ${ }^{2}$ Siti Khalijah Nasiruddin , ${ }^{3}$ Sarina Abdul Halim Lim,${ }^{4}$ Syafinaz Ruslan \\ ${ }^{1}$ Universiti Putra Malaysia : s_fatimah@upm.edu.my \\ ${ }^{2}$ Universiti Putra Malaysia : sitikhalijah448@gmail.com \\ ${ }^{3}$ Universiti Putra Malaysia : sarinalim@upm.edu.my \\ ${ }^{4}$ Universiti Putra Malaysia : syafinazruslansr@gmail.com
}

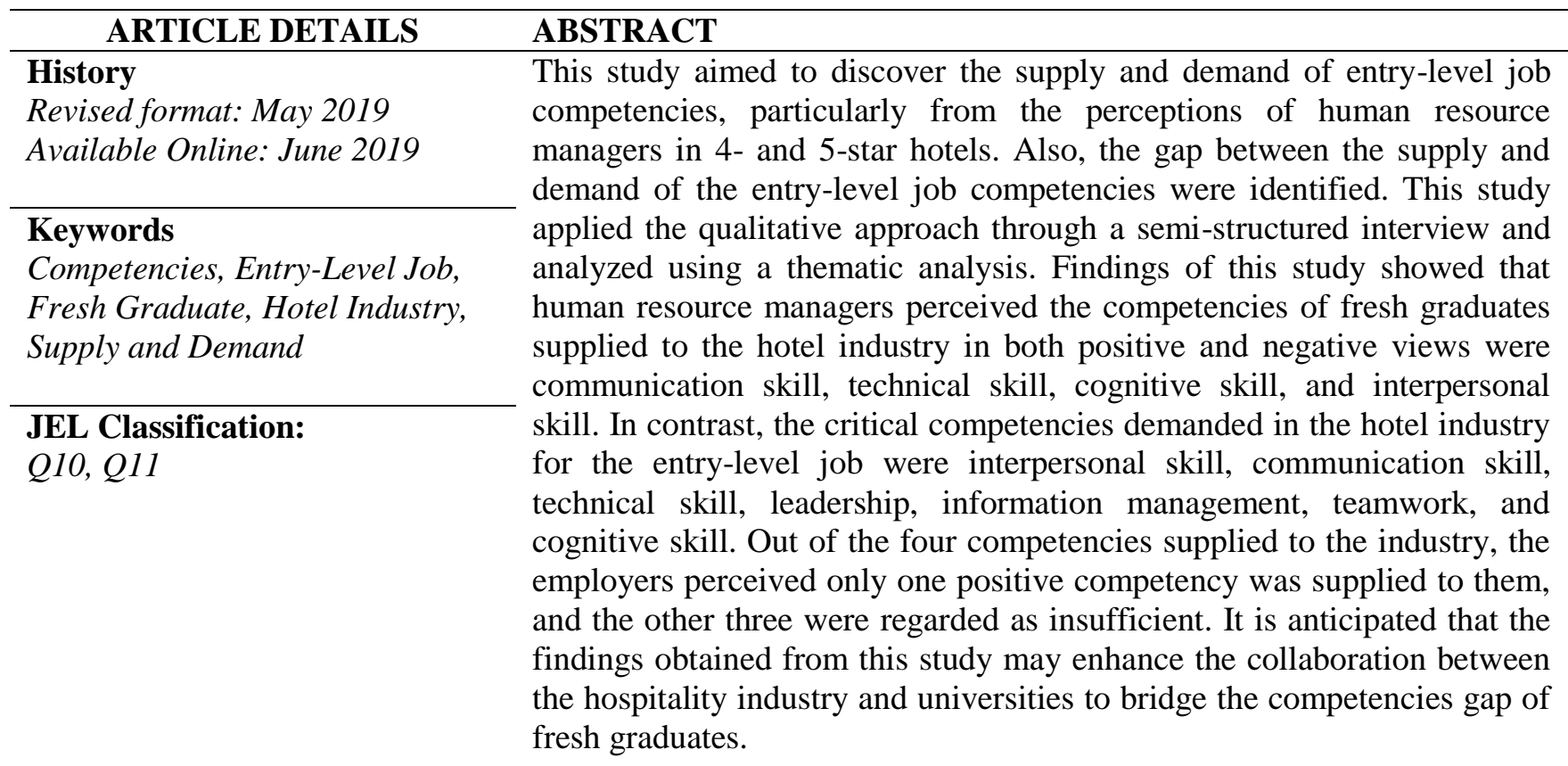

(C) 2019 The authors, under a Creative Commons AttributionNonCommercial 4.0

Corresponding author's email address: kabirbumarmusa@gmail.com

Recommended citation: Mohamad, S. F., Nasiruddin, S. K., Lim, S. A. H., and Ruslan, S. (2019). Supply and Demand of the Entry-Level Job Competencies in the Hotel Industry. Journal of Business and Social Review in Emerging Economies, 5 (1), 181-190

DOI: $10.26710 / \mathrm{jbsee.v5i1.544}$

\section{Introduction}

There is a consistent growth of the hospitality industry, particularly the hotel sector, starting from the twentieth century, and it was projected to continue to remain strong at five to six percent growth in 2018 ("2018 Travel and hospitality industry outlook," 2018; "Hotels worldwide - important statistics", 2018). Though there is a steady growth portrayed by this industry, high employee turnover is a never-ending issue to the hospitality industry (Birdir, 2002; Emiroğlu, Akova, \& Tanriverdi, 2015; Ghiselli, La Lopa, \& Bai, 2001; Nor, Noor, Ahmad, Khalid, \& Ibrahim, 2017; Yao, Qiu, \& Wei, 2019). Turnover is not the only issue in the hospitality industry. Beesley and Davidson (2013) examined the skills shortages in the hospitality industry and reported that there was an imbalance between the skills supply and demand. As such, the unemployment issue raised due to the mismatch between the supplied and demanded skill sets, where the education providers were struggling to overcome the educational 
mismatch (Hanapi \& Nordin, 2014; Lillo-Bañuls \& Casado-Díaz, 2015; Sam, 2018). Managers criticized fresh graduates were incompetent, and this claim led to the dynamic review of curriculum structure which incorporated various strategies in the educational module (Beckley, 2002; Chan, Fong, Luk, \& Ho, 2017; Chang \& Yeado, 2003). Efforts have been taken to reduce turnover as well as incompetencies, by identifying essential skills needed in the hospitality industry and professional development (Chung-Herrera, Enz, \& Lankau, 2003; Guglielmino \& Carroll, 1979; Kay \& Russette, 2000; Milman \& Ricci, 2004; Bharwani \& Jauhari, 2013).

The current Malaysian Prime Minister, Tun Mahathir Mohamad, sees Vision 2020 as Vision 2025 (Sim, 2018) and there will be a higher expectation among the skills demanded in the labor market as we are moving towards the era of Industry Revolution 4.0. The Education Blueprint 2015-2025 portrayed a framework of a higher educational institution with less focusing on traditional and academic pathways and placed an equal value on much-needed technical and vocational training which will provide competent fresh graduates. On the other hand, the government also believed that there is no such commodity as instant graduates, but they have the privilege to expect the availability of fresh graduates with the relevant basic knowledge and skills from the higher educational institutions (Ministry of Education Malaysia, 2015). It is critical to ensure that the academic curriculum and training system meet both the educational and the industry expectations, particularly within the context of the hospitality management (O’Mahony, McWilliams, \& Whitelaw, 2001; Purcell \& Quinn, 1996; Zaitseva, Kozlov, \& Nikolskaya, 2017).

This study aimed to explore the supply of fresh graduates' competencies; the demand for entry-level job competencies; and to identify the gap between the supply and demand of the entry-level job competencies, from the perceptions of hotel managers. By determining the relevant job competencies, it is anticipated to facilitate hotel human resources managers in selecting and hiring employees, that later will ease the career planning initiatives.

\section{Literature Review}

\subsection{Defining Competency}

High employee turnover is a never-ending issue to the hospitality industry, specifically the hotel and foodservice sectors (Birdir, 2002; Brown, Thomas, \& Bosselman, 2015; Ghiselli, La Lopa, \& Bai, 2001; Milman \& Ricci, 2004). Both higher education institutions and industry are striving to improve graduates' employability and employee retention by developing strategies and recognizing key competencies in the workforce (Chung-Herrera, Enz, \& Lankau, 2003; Cloutier et al., 2015; Kay \& Russette, 2000; Milman \& Ricci, 2004; Suleman, 2016). Understanding employment competencies desired by hospitality managers is the responsibility of educators in higher institutions. The relationship between educational factors and employability is an important understudied area in the hospitality literature that need to be discovered more over time (Dittman, 1997; Hsu, Gilmore, \& Walsh, 1992; Tas, 1988; Eurico, da Silva, \& do Valle, 2015).

The competency concept became one of the key literature in the management strategy field since the 1990s, where core competency is identified as an asset to increase individual's competitive advantage (Mitrani, Dalziel, \& Fitt, 1992). There are a few meanings of competency incorporating intentions, convictions, and qualities (Mirabile, 1997). Bird and Pearson (2000) defined competency as the skills, knowledge and other attributes that lead to the success of a chosen area. Meanwhile, Mitchelmore and Rowley (2010) viewed competencies as the combination of observable and applied knowledge, skills and behaviors that create a competitive advantage to an organization. Competency is a reflection to the job performance as employers would have a strategy and target in amplifying employee's abilities to perform a job (Naquin \& Holton, 2003). Jackson (2009) categorized competency into technical competency and managerial competency. On the other hand, Bharwani and Talib (2017) proposed three categories of competency: cognitive competency, functional competency, and social competency. Cognitive competency refers to knowledge-related competency, while functional and social competencies refer to technical skills, behaviors and attitudes skills, respectively. Though different researchers have different categories for competency, employee's competencies in the hospitality industry are essential to help in engendering a memorable hospitality experience (Bharwani \& Jauhari, 2013).

\subsection{The Competencies Supplied to the Industry}

The latest Malaysian Qualifications Framework (MQF) proposed five clusters of learning outcomes to be followed by higher education institutions in Malaysia: i) knowledge and understanding, ii) cognitive skills, iii) functional work skills with focus on practical skills, interpersonal skills, communication skills, digital skills, numeracy skills, leadership, autonomy and responsibility, iv) personal and entrepreneurial skills, and finally v) ethics and 
professionalism (Malaysian Qualifications Agency, 2017). The previous MQF only proposed eight components of the competencies to be mapped in the learning outcomes, comprise: i) knowledge, ii) problem solving and scientific skill, iii) practical skill, iv) communication, leadership, team skills, v) social skills and responsibilities, vi) value, attitudes and professionalism, vii) managerial and entrepreneurial skills, and finally viii) information management and lifelong learning skills (Malaysian Qualifications Agency, 2007).

Though the above skills were infused in most of the university curriculum, there was still an imbalance between the supply and demand of graduates' competencies (Goldsmith \& Mohd Zahari, 1994; Teijeiro, Rungo, \& Freire, 2013). Researchers suggested different approaches and strategies to fill in the skill gap and to improve the collaboration among the industry, university and government (Goldsmith \& Mohd Zahari, 1994; Jackson, 2009; Yunus, 2015). It is reported that fresh local graduates, particularly in Malaysia, were theoretically-trained in the areas of their specialization but lack of soft skills, including critical thinking, communication skill, and poor English proficiency (Azmi, Hashim, \& Yusof, 2018; Goldsmith \& Mohd Zahari, 1994; Singh \& Singh, 2008). Azmi et al. (2018) identified 12 crucial employability skills perceived by undergraduates: disciplined, responsibility, positive attitude, time management, teamwork, open-minded, transparent, communication skills, leadership skills, creative and innovative, appearance, and finally stress endurance. The skills were listed accordingly, started from the most important to the least. However, these skills were perceived by undergraduates from various programs, where the study was not conducted within a specific degree program.

\subsection{The Competencies Demanded by the Industry}

In the 1980s, fundamental competencies for managers required by the hotel industry consisted of comprehensiveness in overseeing visitor issues, commit to the workplace morale, provide sufficient written and oral communication, exert proficient appearance and balance, build a positive relationship with clients and subordinates (Tas, 1988). As time changes, the above competencies were no longer viewed as essential competencies to the industry. Changes in workforce demographics, economic, technology and globalization affected the environment of the hotel industry (Dessler, 2013). Raybould and Wilkins (2006) listed nine most important generic skills perceived by the hospitality managers, with the most important skill was interpersonal skills, followed by problem-solving, self-management, teamwork and leadership, adaptability and learning, written communication, oral communication, conceptual and analytical, and the least important skill was information management. Likewise, the competencies suggested by Jackson (2009) applied to the 21st century, for example, the effective development of solutions that require the application of technology, motivating and mentoring techniques, and solving issues with stakeholders. Recruiters have long proposed that new hires require a blend of experience, readiness, managerial and technical skills which include exhibit authority capacity, create positive client connection and tackle their issues, ability to communicate, self-control, uplift state of mind, human aptitudes, conflict resolution, and ability to empathize (Josiam, Devine, Baum, Crutsinger, \& Reynolds, 2010; Nelson \& Dopson, 2001; Tesone \& Ricci, 2012; Zopiatis, 2007; Ahmad \& Pesch, 2017).

\section{Research Methodology}

\subsection{Research Design and Instrumentation}

Qualitative research design has been chosen as this study aimed to explore the manager's perception regarding the competencies supply and demand of the entry-level jobs in the hotel industry. By employing a qualitative study, a researcher can have a better understanding and gain in-depth information on a particular topic (Creswell, 2009). This study was conducted in the Klang Valley area where 4- or 5- star hotels were chosen as the sample. The selection of this hotel group was due to the large size and systematic human resource practices, as compared to 1- to 3-star hotels (Nasurdin, Ahmad, \& Tan, 2016). The unit analysis of this study was the human resource or training manager, and the purposive sampling was employed for this study. Purposive sampling involves identifying a group of individuals with specific characteristics (Creswell, 2009). The sample of this study was chosen based on certain criteria: 1) hotel manager, 2) involved in the recruitment process, and 3) possessed more than one-year experience in the current position or the hospitality industry. The interviews were conducted in both English and Malay languages, depending on the respondent's convenience. Data saturation was attained from eight managers of 4- and 5- star hotels in Klang Valley. The semi-structured questions were applied in the interview with the help of prompt and probe questions. The questions comprised of three parts: 1) introductory questions to get acquainted with the respondents, 2) the competencies of fresh graduates that they experienced, and 3) the demand of entry-level job competencies in the manager's hotel. The definition of fresh graduates within the scope of this study was given to the interviewee to ensure the responses would be within the context of this study. The context of fresh graduates in 
this study was the undergraduates from local public and private universities who were recently graduated from the hospitality degree.

\subsection{Data Analysis}

Thematic analyses of the translated transcripts were carried out for the data analysis. The coding process was made based on the literature review and emergent codes found in this study were used to identify themes related to the competencies of the entry-level job. The data analysis started by organizing and preparing the data for analysis which included transcribing interviews, sorting and creating notes. Then, the data was coded by bracketing chunks or writing word representing the theme in the margins. This process includes capturing data, segmenting sentences or paragraphs into categories, and labeling the categories with a term based on the actual language of the informants (Creswell, 2009). The validity of the data was ensured by peer debriefing, which involves locating a peer debriefer who reviews and asks questions about the qualitative study, in order to verify that the study resonates with people other than the researcher (Creswell, 2009). Academic experts within the field were invited for this test and validated the themes emerged in this study.

\section{Results and Discussion}

A total of eight hotel managers in Kuala Lumpur participated in this study, comprised of seven 5-star hotels and one 4-star hotel. There was an equal distribution of the manager's gender: female and male. One of the managers is non-Malaysian, and the rest are Malaysians. The positions of the respondents were director and vice presidents of human resources, training manager and human capital development manager. They have one to four years of experience in the hospitality industry.

The hotels in this study offered the managerial position and non-managerial position to fresh graduates. The management trainee was the managerial position given to fresh graduates who have graduated less than twelve months, and they need to undergo on-the-job training for 12 months or more depending on the performance. Meanwhile, the non-managerial position included guest service agent, waiter, housekeeper, and account receivable clerk. Majority of the respondents informed that they offered non-managerial positions.

"......we call that management trainee or voyage in the hotel chain. We are offering to the fresh graduates that have graduated not less than 12 months. They will join us, and we train them up to the managerial level." (R2)

"Normally, it's a service staff for fresh graduates. For operation, guest service agent in the front office, a waiter in the food and beverage department, housekeeper, other departments depend on the position like account receivable." (R1)

"Normally, it's a service staff for fresh graduate." (R6)

\subsection{The Competencies of Fresh Graduates Supplied to the Hotel Industry}

The competencies of fresh graduates perceived by the hotel managers were mentioned in both positive and negative views, which were: 1) communication skill, 2) technical skill, 3) interpersonal skill and 4) cognitive skill. The competencies were arranged from the highest to the lowest weightage, or the frequency mentioned by the managers. Only one competency, the cognitive skill, was viewed as the real competency in this study and the other three were viewed as incompetent. The perceptions given by the hotel managers were based on their experience and observation.

The fresh graduates were able to speak in the English language though not fluent and lack of confidence. The managers also experienced with some of the candidates that communicated in both English and Malay languages during the interview, where they called as "rojak".

"The students from East coast Malaysia are good people but lack in English and confident." (R1)

This statement is in line with the statement from the Malaysian Employers Federation stating that poor command of English was the reason for graduate unemployment (HR in Asia, 2018). The managers also claimed that due to low confidence, it gave a bad impression towards the recruiters. The communication skill supplied to them was insufficient and not up to their expectation. 
The managers viewed basic technical skills were needed in the entry-level job for fresh graduates like cooking and computer skill. They never doubt that fresh graduates were good in theoretical knowledge. However, the managers claimed that graduates have a minimum amount of hands-on skill and not practically well-trained.

“...because we have students that come from hospitality school and they never see a functional kitchen or a functional room. They just study theory. In the hospitality field, you cannot study only from theory, you need to feel things, you need to do things, and you know how to do things." (R6)

The lack of technical skill has caused the hotels to spend more time and money in giving training to fresh graduates to prepare them for their jobs.

Then, the managers perceived that graduates were incompetent in term of the interpersonal skill, which elaborated as a lack of willingness to learn and lack of positive attitude. The fresh graduates refused to learn new things in the work environment, particularly the hotel system. This created difficulties to the hotel managers in motivating them to fit in with the work culture. Besides, the managers stated that they prefer to have an unskilled employee who can be trained but lack of attitude cannot be tolerated.

"Some of the graduates reveal their bad attitude during the probation period, and we will not offer them the position which will affect the hotel performance in future" (R5)

Finally, the only competency satisfied by the hotel managers was the cognitive skill. The fresh graduates were theoretically ready for the workplace. They possess knowledge that they learned from the university. Nonetheless, the managers reported it was insufficient to have knowledge but lack of hands-on practice.

"They are theoretically ready but not in practical or hands-on work" (R5)

\subsection{The Competencies of the Entry-Level Job Demanded by the Hotel Industry}

There are seven competencies demanded by the hotel industry, as perceived by the hotel managers in this study. The competencies of the entry-level job were listed from the highest to the lowest weightage. The competencies were: 1) interpersonal skill, 2) communication skill, 3) technical skill, 4) leadership, 5) information management, 6) teamwork, and 7) cognitive skill.

The interpersonal skill was the most frequent skill stated by the hotel managers, which comprised bold personality, willingness to learn, attitude and people-oriented. Human interaction is much important in the hotel industry, and the managers require graduates with attractive personalities to join their organization. The managers would hire candidates who show strong personality and able to convince them that the graduates can cope with the working environment.

“... a bold or good personality will be an advantage for them." (R7)

"They would like people who love to smile or talkative or love talking to people. This kind of people that we are looking at for the job." (R5)

The next competency required for the entry-level job in the hotel industry was communication skill, which consisted of English proficiency, confidence, and writing skill. The managers reported that effective and professional communication is important for positions in hotel management, food and beverage management, and club management. Verbal communication is critical in interacting with guests, and it reflects the hotel's image. The hotel managers emphasized the English proficiency as one of the competencies demanded from fresh graduates, particularly for the front of the house positions and managerial positions. In addition, writing skill was perceived as the component of communication needed in relation to the documentation job within the hotel industry.

“... make a formal letter or formal document according to hotel standard is one of their jobs" (R5)

The technical skill demanded by the hotel industry comprises cooking and computer skill. Cooking skill is important for kitchen staffs while computer skill is important to almost every department in a hotel. The managers perceived that the entry-level position should possess basic knowledge in using Microsoft Office. Meanwhile, the 
level of cooking skill was determined based on the chef hierarchy, and the higher position would require a difficult cooking test.

"... the cooking test for CDP (chef de partie) but the commis position, they need to know the basic cooking only and undergo a regular entry-level test." (R3)

Leadership qualities and self-determination were the components belong to the next skill, leadership. The hotel industry required graduates who can self-develop, where this group of people knows what to do in achieving personal or organization goals without being instructed. The managers perceived that some people were born to be a leader, but leadership can be developed from time to time, depending on the employee's willingness to infuse the leadership traits and via training provided by the hotel. Also, the managers believed that experience is an important aspect to become a good leader.

"Another thing is about leadership skill; it is needed if you want to become a manager, you should have leadership in a way for you to lead others. Sometimes it comes naturally to the individual itself." (R7)

Although the information management was not in the list of the high weightage skills mentioned in this study, it was still demanded by the hotel industry. The information management skill required by the industry referred to the paperwork management. At the starting point in the entry-level job, mainly to the managerial position, employees have to do a lot of documentation and paperwork as they assist the manager. The responsibilities include writing a formal letter, filing documents and preparing files for the company's records. Thus, the entry-level employees should know how to manage available information in the hotel to ensure the operation remains smooth and escalate the productivity of the business.

"The graduates need to have basic management skill as they will start with basic work that required lots of documentation" (R6)

The lowest weightage of the competencies demanded by the industry were teamwork and cognitive. The managers perceived teamwork was needed for the entry-level job as the hotel organization comprised several departments and required cross-communication to ensure the hotel operation runs smoothly. On the other hand, knowledge was still considered as the competency needed not only by the hotel industry, but to all types of industry. Without the fundamental knowledge related to the field, candidates will not be hired for the entry-level job.

".... they should be theoretically ready ...." (R5)

\subsection{The Gap between the Supply and Demand of the Entry-level Job Competencies}

It can be concluded that there was a gap between the supply and demand of the entry-level job competencies to the hotel industry in Klang Valley. By comparing both the competencies supplied and demanded perceived by the hotel managers, the only supplied competency that met the industry's expectation was the cognitive skill. The other three competencies supplied to the industry: communication skill, technical skill, and interpersonal skill were viewed as insufficient or incompetent. Table 2 shows the comparison between the supplied and demanded competencies of the entry-level job in the hotel industry. The competencies are listed according to the weightage or frequency mentioned in the interviews.

Table 2: Comparison between the Supplied and Demanded Competencies of the Entry-Level Job in the Hotel Industry

\begin{tabular}{|l|l|l|l|l|l|}
\hline No. & Supplied Competencies & $\begin{array}{l}\text { Weightage/ } \\
\text { Frequency }\end{array}$ & No. & $\begin{array}{l}\text { Demanded } \\
\text { Competencies }\end{array}$ & $\begin{array}{l}\text { Weightage/ } \\
\text { Frequency }\end{array}$ \\
\hline 1. & Communication skill (-ve) & 10 & 1. & Interpersonal skill & 17 \\
\hline 2. & Technical skill (-ve) & 8 & 2. & Communication skill & 14 \\
\hline 3. & Interpersonal skill (-ve) & 7 & 3. & Technical skill & 9 \\
\hline 4. & Cognitive skill (+ve) & 2 & 4. & Leadership & 5 \\
\hline & & & 5. & $\begin{array}{l}\text { Information } \\
\text { management }\end{array}$ & 3 \\
\hline & & & 6. & Teamwork & 2 \\
\hline
\end{tabular}




\begin{tabular}{|l|l|l|l|l|l|}
\hline & & & 7. & Cognitive skill & 2 \\
\hline
\end{tabular}

$(-\mathrm{ve})=$ incompetent,$(+\mathrm{ve})=$ competent

The results were in line with the report stated in the Malaysian Education Blueprint 2012-2025. There was a mismatch between the supply and demand of graduates' competencies, where employers reported that graduates were lack of skills and attitudes (Ministry of Education Malaysia, 2015). The managers in this study suggested a few approaches to overcome the mismatch, including 1) implementing buddy systems for an internship programme and newcomers like fresh graduates, 2) create excitement in the work environment to motivate new employees, 3) give training to employees.

\section{Conclusion}

This study explored the supplied and demanded competencies for the entry-level jobs as perceived by the hotel managers in Klang Valley. It is found that out of four supplied competencies, only one competency matched with the demanded competencies, which is the cognitive skill. The three competencies supplied to the industry were regarded as incompetent: communication skill, technical skill, and interpersonal skill. The managers perceived that there were seven key competencies needed by the industry: 1) interpersonal skill, 2) communication skill, 3) technical skill, 4) leadership, 5) information management, 6) teamwork and 7) cognitive skill. Obviously, the managers were not satisfied with the competencies supplied to them. Though the curriculum in public universities has been improved from time to time, the gap between the competencies supply and demand is still persistent. The managers recommended a few suggestions to solve the issue.

This study is anticipated to give an insight about the components and descriptions of the supply-demand competencies to all the stakeholders: undergraduates, fresh graduates, academics, higher education institutions, the Malaysian government, and the hotel industry. By understanding the mismatch, undergraduates would have an awareness to be more proactive in developing their skills once they have enrolled in the hospitality program. Fresh graduates would know how to strategize in presenting themselves during an interview. Academics and higher education institutions would review and improve the curriculum program to escalate the employability of their graduates. The coordination between the government and the hotel industry was anticipated to resolve this issue. It is suggested to further investigate the issue by examining the perception of undergraduates and academics. The motivation, challenges and constraints in possessing the competencies can be explored.

\section{References}

2018 travel and hospitality industry outlook. (2018, Sept. 15). Retrieved from https://www.apastyle.org/learn/faqs/web-page-no-author.aspx

Ahmad, S., \& Pesch, M. (2017). Essential work skills and readiness: Perceptions of employers, MBA students and undergraduates. Academy of Educational Leadership Journal, 21(1), 1-10.

Azmi, I. A. G., Hashim, R. C., \& Yusoff, Y. M. (2018). the employability skills of Malaysian university students. International Journal of Modern Trends in Social Sciences, 1(3), 01-14.

Bharwani, S., \& Jauhari, V. (2013). An exploratory study of competencies required to co-create memorable customer experiences in the hospitality. International Journal of Contemporary Hospitality Management, 25(6), 823-843.

Bharwani, S., \& Talib, P. (2017). Competencies of hotel general managers: A conceptual framework. International Journal of Contemporary Hospitality Management, 29(1), 393-418.

Beckley, M. J. (2002). Development opportunities in the Canadian hotel market. Journal of Retail \& Leisure Property, 2(4), 332-337.

Beesley, L. G. \& Davidson, M. (2013). A critical analysis of skilled labor supply and demand in the Australian hospitality industry. Journal of Quality Assurance in Hospitality \& Tourism, 14(3), 264-280.

Birdir, K., \& Pearson, T. E. (2000). Research chefs' competencies: a Delphi approach. International journal of contemporary hospitality management, 12(3), 205-209.

Birdir, K. (2002). General manager turnover and root causes. International journal of contemporary hospitality management, 14(1), 43-47.

Brown, E. A., Thomas, N. J., \& Bosselman, R. H. (2015). Are they leaving or staying: A qualitative analysis of turnover issues for Generation Y hospitality employees with a hospitality education. International Journal of Hospitality Management, 46(2015), 130-137.

Chan, C. K., Fong, E. T., Luk, L. Y., \& Ho, R. (2017). A review of literature on challenges in the development and implementation of generic competencies in higher education curriculum. International Journal of 
Educational Development, 57, 1-10.

Chang, J., \& Yeado, B. (2003). Where the jobs are. Sales \& Marketing Management, 155(6), 32-32.

Chung-Herrera, B. G., Enz, C. A., \& Lankau, M. J. (2003). A Competencies Model. Cornell hotel and restaurant administration quarterly, 44(3), 17-25.

Cloutier, O., Felusiak, L., Hill, C., \& Pemberton-Jones, E. J. (2015). The importance of developing strategies for employee retention. Journal of Leadership, Accountability and Ethics, 12(2), 119-129.

Creswell, J. W. (2009). Research design: Qualitative, quantitative and mixed approaches (3rd edition). CA: Sage.

Dessler, G. (2013). Human resource management (13th ed.). London: Pearson.

Dittman, D. A. (1997). Reexamining curriculum. Cornell hotel and restaurant administration quarterly, 38(6), 3.

Emiroğlu, B. D., Akova, O., \& Tanrıverdi, H. (2015). The relationship between turnover intention and demographic factors in hotel businesses: A study at five star hotels in Istanbul. Procedia-Social and Behavioral Sciences, 207, 385-397.

Eurico, S. T., da Silva, J. A. M., \& do Valle, P. O. (2015). A model of graduates' satisfaction and loyalty in tourism higher education: The role of employability. Journal of Hospitality, Leisure, Sport \& Tourism Education, 16(2015), 30-42.

Ghiselli, R. F., La Lopa, J. M., \& Bai, B. (2001). Job satisfaction, life satisfaction, and turnover intent among foodservice managers. Cornell hotel and restaurant administration quarterly, 42(2), 28-37.

Guglielmino, P. J., \& Carroll, A. B. (1979). The hierarchy of management skills: Future professional development for mid-level managers. Management decision, 17(4), 341-345.

Goldsmith, A., \& Mohd Zahari, M. S (1994). Hospitality education in Malaysia: Filling the skill gap. International Journal of Contemporary Hospitality Management, 6(6), 27-31.

Hanapi, Z., \& Nordin, M. S. (2014). Unemployment among Malaysia graduates: Graduates'attributes, lecturers' competency and quality of education. Procedia - social and behavioral sciences, 112, 1056-1063.

Hotels worldwide $\quad-\quad$ important statistics. (2018, $\quad$ Sept. 15). Retrieved from https://www.statista.com/topics/1102/hotels/

HR in Asia. (2018, January 24). Poor command of English among major reasons for graduates unemployment in Malaysia. Retrieved from http://www.hrinasia.com/recruitment/poor-command-of-english-among-majorreasons-for-graduates-unemployment-in-malaysia/

Hsu, C. H., Gilmore, S. A., \& Walsh, T. E. (1992). Competencies needed and demonstrated by hospitality management graduates: Perceptions of employers. National Association of College and University Food Service Journal, 16, 34-42.

Jackson, D. (2009). Profiling industry-relevant management graduate competencies: The need for a fresh approach. International Journal of Management Education, 8(1), 85-98.

Josiam, B. M., Devine, F. G., Baum, T., Crutsinger, C., \& Reynolds, J. S. (2010). Attitudes to work of generation Y students in hospitality management: A comparative analysis of students in England, Scotland and Northern Ireland. Journal of hospitality \& tourism education, 22(1), 44-53.

Kay, C., \& Russette, J. (2000). Hospitality-management competencies: Identifying managers' essential skills. Cornell hotel and restaurant administration quarterly, 41(2), 52-63.

Lillo-Bañuls, A., \& Casado-Díaz, J. M. (2015). Exploring the relationship between educational mismatch, earnings and job satisfaction in the tourism industry. Current Issues in Tourism, 18(4), 361-375.

Malaysian Qualifications Agency. (2007). Malaysian Qualifications Framework (MQF). Putrajaya.

Malaysian Qualifications Agency. (2017). Malaysian Qualifications Framework (MQF) 2nd Edition. Putrajaya.

Milman, A., \& Ricci, P. (2004). Predicting job retention of hourly employees in the lodging industry. Journal of hospitality and tourism management, 11(1), 28-41.

Ministry of Education Malaysia. (2015). Executive summary: Malaysia Education Blueprint 2012-2025 (Higher Education). Putrajaya: Ministry of Education.

Ministry of Higher Education Malaysia. (2006). Soft skills development module for Malaysian institutions of higher learning. Universiti Putra Malaysia.

Mirabile, R. J. (1997). Everything you wanted to know about competency modeling. Training \& development, 51(8), 73-78.

Mitchelmore, S., \& Rowley, J. (2010). Entrepreneurial competencies: a literature review and development agenda. International journal of entrepreneurial behavior \& research, 16(2), 92-111.

Mitrani, A., Dalziel, M., \& Fitt, D. (1992). Competency based human resource management: Value-driven strategies for recruitment, development and reward. London: Kogan Page Ltd.

Naquin, S. S., \& Holton, E. F. (2003). Redefining state government leadership and management development: A process for competency-based development. Public personnel management, 32(1), 23-46. 
Nasurdin, A. M., Ahmad, N. H., \& Tan, C. L. (2016). The role of staffing and orientation practices in predicting service-oriented organisational citizenship behaviour. Asian Academy of Management Journal, 21(2).

Nelson, A. A., \& Dopson, L. (2001). Future of hotel education: Required skills and knowledge for graduates of U.S. hospitality programs beyond the year 2000 -part one. Journal of hospitality and tourism education.

Nor, M. N. M., Noor, A. N. M., Ahmad, Z., Khalid, S. A., \& Ibrahim, I. I. (2017). Factors Affecting Turnover Intention Among Gen Y in Hotel Industry. Jurnal Intelek, 12(1), 1-5.

O'Mahony, G., McWilliams, A.M. and Whitelaw, P.A. (2001), "Why students choose a hospitality degree program", The Cornell hotel and restaurant administration, Vol. 42 No. 1, pp. 92-6.

Purcell, K., \& Quinn, J. (1996). Exploring the education-employment equation in hospitality management: A comparison of graduates and HNDs. International Journal of Hospitality Management, 15(1), 51-68.

Raybould, M., \& Wilkins, H. (2006). Generic Skills for Hospitality Management: A Comparative Study of Management Expectations and Student Perceptions. Journal of hospitality and tourism management, 13(2), $177-188$.

Sam, V. (2018). Unemployment duration and educational mismatches: An empirical investigation among graduates in Cambodia. Economics Bulletin, 38(3), 1554-1565.

Sim, L. L. (2018, June 11). Dr M: Vision 2020 is now Vision 2025. The Star Online. Retrieved from https://www.thestar.com.my/news/nation/2018/06/11/dr-m-vision-2020-is-now-vision-2025/

Singh, G. K. G., \& Singh, S. K. G. (2008). Malaysian graduates’ employability skills. UNITAR e-Journal, 4(1), 1545.

Suleman, F. (2016). Employability skills of higher education graduates: Little consensus on a much-discussed subject. Procedia-Social and Behavioral Sciences, 228, 169-174.

Tas, R. F. (1988). Teaching future managers. Cornell Hotel and Restaurant Administration Quarterly, 29(2), 41-43.

Teijeiro, M., Rungo, P., \& Freire, M. J. (2013). Graduate competencies and employability: The impact of matching firms' needs and personal attainments. Economics of Education Review, 34(2013), 286-295.

Tesone, D.V \& Ricci, P. (2012). Hospitality industry expectations of entry-level college graduates: attitude over aptitude. European journal of business and social sciences, 1(6), 140-149.

Yao, T., Qiu, Q., \& Wei, Y. (2019). Retaining hotel employees as internal customers: Effect of organizational commitment on attitudinal and behavioral loyalty of employees. International Journal of Hospitality Management, 76, 1-8.

Yunus, M. (2015). A comparative study on public-private partnership (PPP) for creating highly skilled and productive business graduate in Bangladesh. Asian Business Review, 3(3), 21-25.

Zaitseva, N. A., Kozlov, D. A., \& Nikolskaya, E. Y. (2017). Evaluation of the competencies of graduates of higher educational institutions, engaged in the training of personnel for tourism and hospitality. Eurasian Journal of Analytical Chemistry, 12(5b), 685-695.

Zopiatis, A. (2007). Hospitality internships in Cyprus: A genuine academic experience or a continuing frustration?. International Journal of Contemporary Hospitality Management, 19(1), 65-77. 